\title{
UNIVERSITY OF CALIFORHIA
}

LIVERMORE

\section{Preliminary Thoughts on Reactor Optimization Criteria}

\author{
Norman Brown
}

July 7, 1967

\section{LEGAL NOTICE}

(1) United This report was prepared as an account of Government spont of the Commission:

States, nor the Commission, nor any person acting on behalf of the Coms A. Makes any warranty or representation, expressed or implied, with respeot the the A. Makes any war or usefulness of the information contained in this report, or that the use

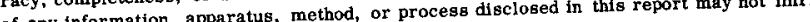
of any inform

privately owned right or the B. Assumes any liabilities with respect to the use of, or for damases reselost.

use of any information, apparatus, method, or process dhe Commission" includes any emAs used in the above, "person acting on behalf of the Com contractor, to the extent tha ployee or contractor of the Commlssion, or emplos such employee or contractor of the Commission, or emplont to his employment or contract disseminates, or provides access to, any information pursuant 


\section{DISCLAIMER}

This report was prepared as an account of work sponsored by an agency of the United States Government. Neither the United States Government nor any agency Thereof, nor any of their employees, makes any warranty, express or implied, or assumes any legal liability or responsibility for the accuracy, completeness, or usefulness of any information, apparatus, product, or process disclosed, or represents that its use would not infringe privately owned rights. Reference herein to any specific commercial product, process, or service by trade name, trademark, manufacturer, or otherwise does not necessarily constitute or imply its endorsement, recommendation, or favoring by the United States Government or any agency thereof. The views and opinions of authors expressed herein do not necessarily state or reflect those of the United States Government or any agency thereof. 


\section{DISCLAIMER}

Portions of this document may be illegible in electronic image products. Images are produced from the best available original document. 
SPACE POWER NOTE NO. 225 - JUIY 7, 1967

AUTHOR: N. Brown

SUBJECT: Preliminary Thoughts on Reactor Optimization Criteria

\section{ABSTRACT}

The problem of selecting the optimum fuel element configurations for reactors covering the range from 1 to $100 \mathrm{Mw}$ th is examined briefly, and a few preliminary criteria are established for a first approximation.

The primary purpose of the Space Power Reactor Program is to acquire the technology to design and build large liquid metal cooled reactors. It was recognized early that the power range from 1 to $100 \mathrm{Mw}$ thermal involved a transition in the criteria for specifying the reactor design, and the SPR-4 and SPR-6 power levels were selected to exemplify the extremes of this range.

The optimization of these reactors was approached by assembling subroutines into an overali systems code and optimizing the entire system by an approximate steepest descent procedure. This still appears the best procedure in the long run, but it is a slow lengthy procedure $i l l$ suited for broad range, coarse surveys.

Recently there have been a number of requests from AEC, NASA and others for such surveys to be integrated into other studies, indicating the need for a simpler approximation criterion. The following simple calculations represent a first step which will be followed up as time and tools permit. Comments and suggestions will be weicomed.

This first study seeks to establish a method of selecting fuel element geometry as a function of power level and lifetime. A few general conclusions can be drawn but the cautions and "weasel words" must at this point outnumber the conciusions. 
First, only two fuel element types were considered, the spaced pin and the hybrid pin-tube arrangement. These were selected for comparison because they can be bundled together in a similar manner permitting an identical core assembly technique. It must be pointed out that hexagonal tubes have superior thermal stress and pressure drop characteristics. However, these elements present structural problems, associated with swelling, that have not been resolved at this time.

The pin element cores were assumed to be homogeneous cylindrical assemblies with an $L / D$ of 1.2 since it was recognized that this element would be used for the lower power range. In this range criticality dominates the reactor geometry and the refinements of power flattening by a central return duct and shield weight minimization by larger $L / D$ specification are not feasible. The wide lattitude of fuel fraction selection available by selecting the spacing ratio $B$ is of major importance in this range.

A 10,000 hour life and a $70^{\circ} \mathrm{K}$ coolant temperature rise through the core was assumed. Enrichment was assuned to be uniform.

For the pin elements the spacing parameter $B$ was varied from 0 to .16 in four steps of .04. Power levels of 2, 4, 8, 16 and $32 \mathrm{Mw}$ th were selected to correspond to these spacing parameters, and for each pair of values three cores were designed for enrichments of .9, .7, and .5. The design procedure consisted of iterating on the reactor design subroutine (REACT) and a modified DTF-2, 16 group transport subroutine (MDTF) using burnup as an independent variable until the dimensions were consistent with an unreflected core multiplication factor of .95 at hot conditions at the start of life. The calculation included a pressure vessel but the pressure vessel thickness is questionable at this time. The value of .95 allows for startup temperature coefficlents, lack of end reflection in the calculations, etc. Table 1 shows the cases studied. In each case the designs were carried out in much greater detall and additional information is available from the author if required. 
These results may be extrapolated to a wide range of power levels by means of a plotting technique developed by Longo at G. E. * This is shown in Figures $1-5$.

From page 17. Appendix, SPN-155, it can be seen that for a given reactor size and coolant temperature rise the friction pressure drop varies as

$$
\Delta P \propto \frac{0^{1.8}}{r_{f}^{1.2}}
$$

and since for a given stress criterion

$$
\begin{aligned}
& r_{f} \propto Q^{-.5} \\
& \therefore \Delta P \propto Q^{2.4}
\end{aligned}
$$

From this relationship pressure drop could be determined for different power levels for the same reactor. When these were plotted for the three reactors corresponding to the three enrichment levels it was found that the isobars were essentially straight lines on the logarythmic plots.

In a similar fashion curves for constant burnup could be determined since burnup is directly proportional to power.

A plot of enrichment as a function of core weight for the same power level showed that log enrichment was approximately a linear function of $\log$ weight, permitting the other enrichment determinations. Finally the radius reiationship was determined from the fact that weight varies as the cube of the radius.

*J. Longo, Jr., "An Optimization Method of Reactor Sizing Accounting for System and Technological Constraints", Missile and Space Division, General Electric, R67SD3001. 
There are slight errors in extrapolating to different power levels since the swelling allowance in the core is properly computed only for the design power level, etc., but in general the error is less than the plotting error.

The data from Figures 1 through 5 were crossplotted for different power levels as shown in Figure 8 where the core weights and radii at which certain friction pressure drops and burnups occur are plotted as functions of the geometrical parameter $B$. Also.plotted are the weights corresponding to enrichments of $90 \%$ and $100 \%$.

The intersection of a given pressure line with an enrichment or burnup line is seen to result, in the lightest and smallest core that is consistent with these criteria.

These points were then crosspiotted in Figures 9 and 10 to show the loci of the minima. An enrichment of $90 \%$ was assumed to be the maximum feasibie in a preliminary design. Thus Figure 9 shows approximately the minimum weight cores that can be designed using pin type elements consistent with a given pressure drop and 10,000 $\mathrm{hr}$ burnup. This can be extrapolated to other coolant temperature rise conditions by noting that pressure drop varies as

$$
\Delta P \propto \Delta T^{-1.8}
$$

Similarly, since burnup is proportional to life, other lifetimes can be considered. Plots are also included for hybrid element cores, one for a hollow core with a central area 15\% of the active core volume. In this case however the $L / D$ ratio selected was 1.4 . In all cases the radii given are to the inside of the pressure vessel and appropriate allowance has been made for differential expansion due to transients, etc. 
SPN NO. 225 - July 7, 1967

Subj: Preliminary Thoughts on Reactor Optimization Criteria

Page 5

In general, reactor weights calculated (meglecting the shield) ranged from $25 \%$ greater than core weight at the lower end of the power range to $60 \%$ greater at the upper range, and these are probably optimistic by not more than a factor of 2 .

Figure 9 is the most interesting of the curves shown. It shows that up to $2 \mathrm{Mw}$ th, criticality is the dominant factor. Assuming that $2 \%$ to $3 \%$ burnup is acceptable, it shows that low pressure drops may dominate the region to about $10 \mathrm{Mw}$ th. (Pressure drop and reactor radius were the primary topic of the NASA inquiry.) Beyond this range burnup begins to dominate. The hybrid elements show inherently lower pressure drops but are relatively heavy due to their comparatively low fuel fraction until core weight approaches"the 700 to $1000 \mathrm{~kg}$ level. They are superior above this level and the transition range may extend downward somewhat when reliability is taken into account. Surface heat fluxes have been calculated and do not appear to be a problem below $100 \mathrm{Mw}$ th. Above this range they will impose an additional limit.

The hexagonal tube elements will shift these transition ranges to the right, but there are too many questions to be resolved before their use can be considered.

A number of strong cautions must be made here. The cladding thickness to radius ratio used $(, 10)$ may be too small. Optimization should perhaps be made on a radius including the reflector in the extended position rather than on core weight and pressure vessel inside radius. These calculations include a swelling characteristic that has not been verified. No calculations have been made on controllability or stability. Pressure drops shown here are friction losses only and do not show return or minor iosses. Absolute pressure drop may not be as significant as relative. pumping power, although it is felt at this time that the pressure contribution to weight through piping and pressure vessel sizing is more significant than the contribution through system inefficiency which pumping power would measure. Finaliy, the core $L / D$ ratio, the volume fraction of inert 
central regions, a wider range of fuel elements, the criteria for power flattening and the consequent variation of fuel enrichments remain to be examined in more detailed studies.

These calculations have been carried out graphically from a small amount of information. They are however well suited to computer techniques, and it should be possible with a small effort to formalize a procedure for determining optimum parameters for a wide range of constraints.

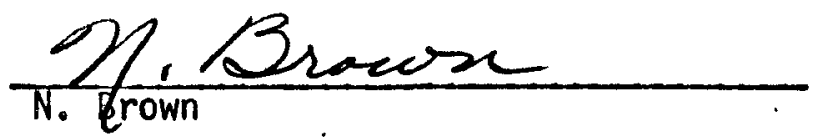

NB:esp

OISTRIBUTION :

J. Hadley

J. Hadley/File (5)

M. Heusinkveld

0. Kolar

G. Cummings

T. Stubbs

J. Howard

W. Loewe

N. Brown

P. Mohr

J. Pitts

B. Myers

B. Myers/File (5)

W. N. Ross

C. Walter

W. Wells
R. Werner

C. Journeay

J. Freeman (2)

L. Roberts

B. Rubin

R. Batzel

R. Heckman

J. Kane

H. Finn

A. Rothman

R. Vandervoort

H. Teifeld

Patent Engineering

Edward S. Wilson, AEC-Washington 


\section{TABLE 1}

\section{CALCULATED CORES}

\begin{tabular}{|c|c|c|c|c|c|c|c|c|c|}
\hline \multirow[b]{2}{*}{ 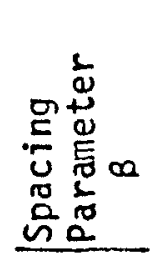 } & \multirow[b]{2}{*}{ 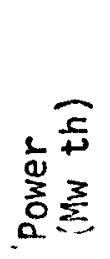 } & \multirow{2}{*}{\multicolumn{2}{|c|}{ 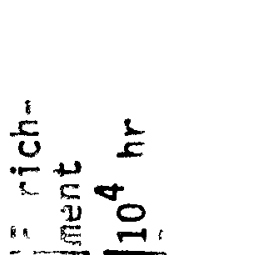 }} & & & \multirow[b]{2}{*}{ 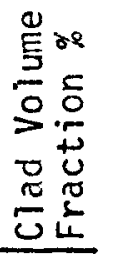 } \\
\hline & & & & 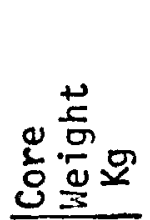 & 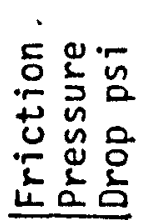 & 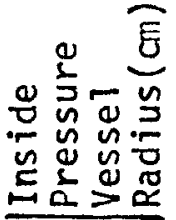 & 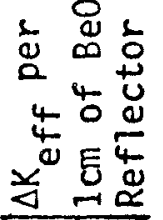 & 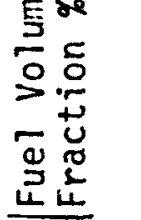 & \\
\hline 0 & 2 & .9 & .7 & 225 & 4.28 & 12.72 & .0509 & $\overline{70.30}$ & 17.23 \\
\hline 0 & 2. & .7 & $.40^{1 x}$ & 338 & 2.40 & 14.50 & .0455 & 71.34 & \\
\hline 0 & 2. & .5 & $.275 T$ & 600 & 1.05 & 17.49 & .0369 & 72.26 & \\
\hline .04 & 4. & .9 & 1.244 & 269 & 3.41 & 13.95 & .0508 & 63.09 & 5.33 \\
\hline .04 & 4. & .7 & .8373 & 399 & 1.97 & 15.79 & .0453 & 64.62 & \\
\hline .04 & 4. & .5 & .4774 & 697 & .887 & 18.91 & .0367 & 66.01 & \\
\hline .08 & 8. & .9 & 2.080 & 329 & 5.50 & 15.44 & .0503 & 55.73 & 6.26 \\
\hline .08 & 8. & .7 & 1.427 & 476 & 3.32 & 17.28 & .0446 & 7.88 & \\
\hline .08 & 8. & .5 & .8249 & 819 & 1.55 & 20.50 & .0359 & 59.96 & 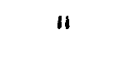 \\
\hline .12 & 26. & .9 & 3.413 & 415 & 11.42 & 17.32 & .0491 & 48.04 & 16.86 \\
\hline .12 & 16. & .7 & 2.394 & 585 & 7.30 & 19.13 & .0433 & .89 & \\
\hline .16 & 32. & .9 & 5.44 & 551 & 25.84 & 19.86 & .0469 & 0.05 & 7.98 \\
\hline .16 & 32. & .7 & 3.92 & 749 & 17.77 & 21.54 & .0413 & 43.53 & 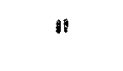 \\
\hline H.S. & 55. & .9 & 7.028 & 776 & 22.39 & 22.12 & .0493 & 33.00 & 8.31 \\
\hline$"$ & 55. & .7 & 5.126 & 2034 & 16.03 & 23.76 & .0431 & 36.54 & . \\
\hline " & 55. & .5 & 3.153 & 1634 & 9.03 & 26.94 & .0338 & 40.76 & " \\
\hline H.H. ${ }^{*}$ & 55. & .9 & 5.354 & 993 & 19.17 & 24.63 & .0533 & 36.09 & \\
\hline$"$ & 55. & .8 & 4.555 & 1154 & 15.98 & 25.62 & .0501 & 37.70 & 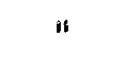 \\
\hline 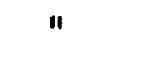 & 55. & .7 & 3.752 & 1385 & 12.72 & 26.93 & .0462 & 39.42 & 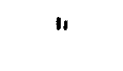 \\
\hline " & 55. & .6 & 2.950 & 1742 & 9.465 & 28.74 & .0414 & 41.24 & 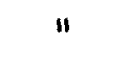 \\
\hline " & 55. & .5 & 2.151 & 2362 & 6.310 & 31.45 & .0354 & 43.16 & \\
\hline
\end{tabular}




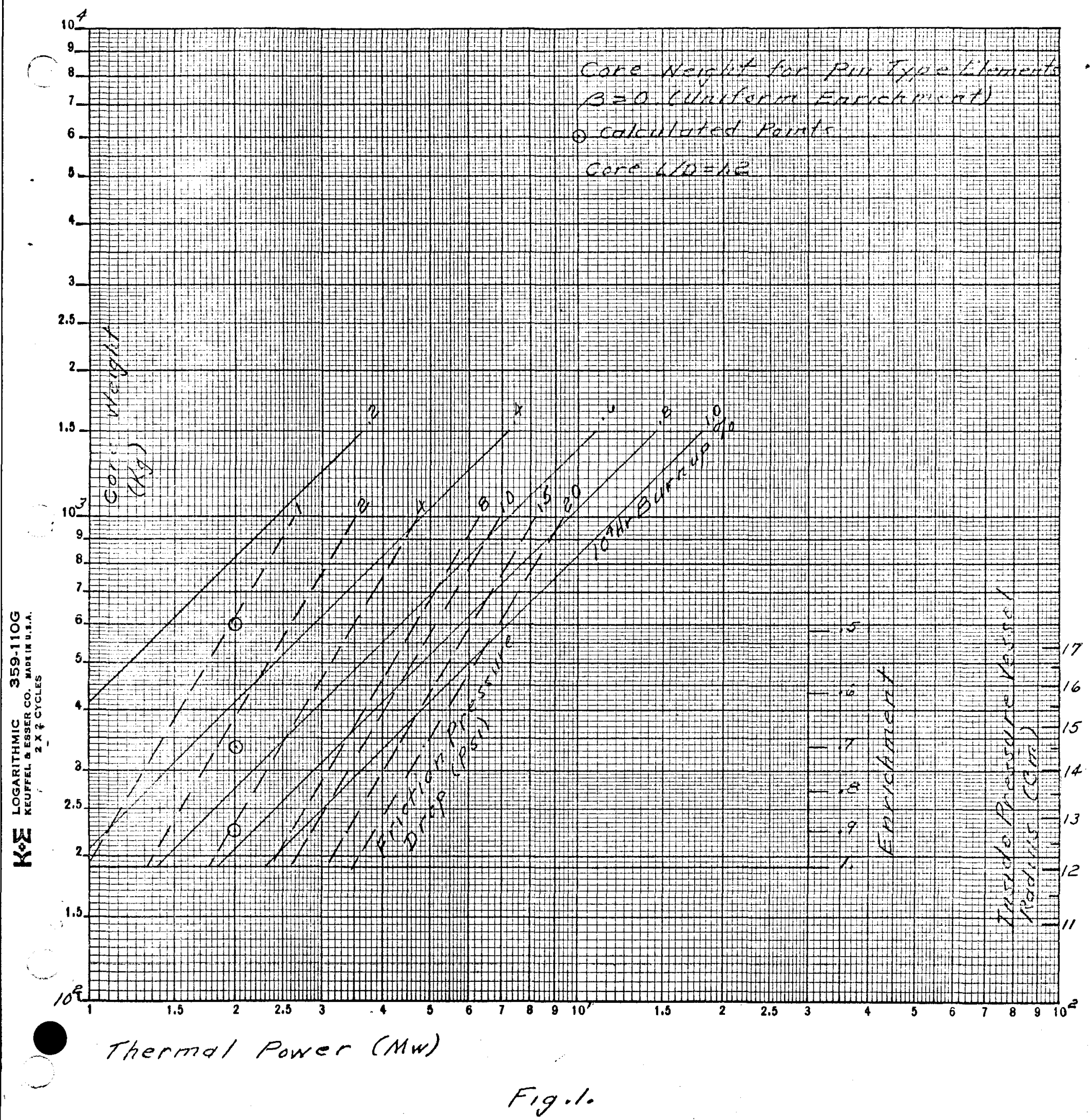




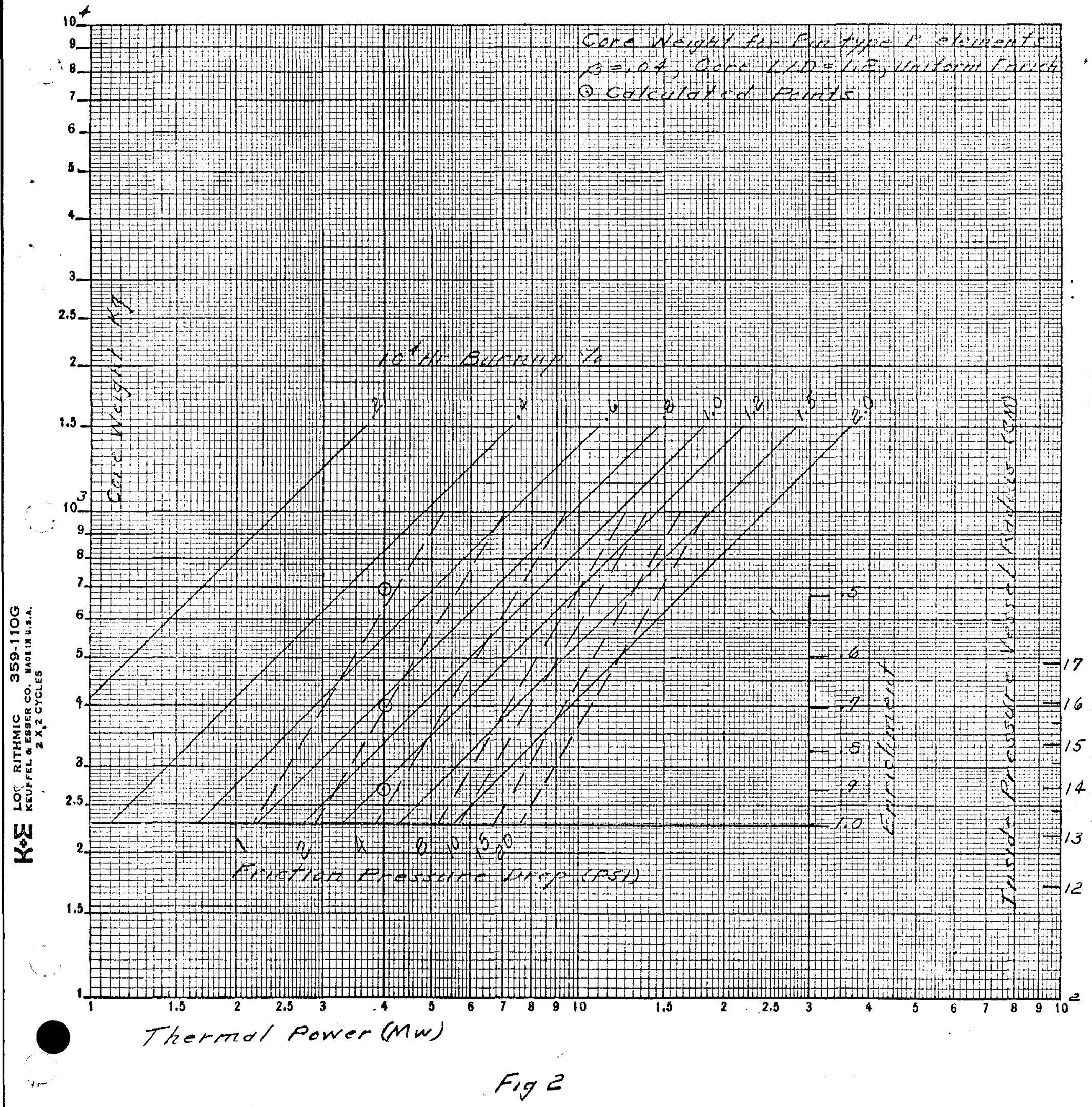




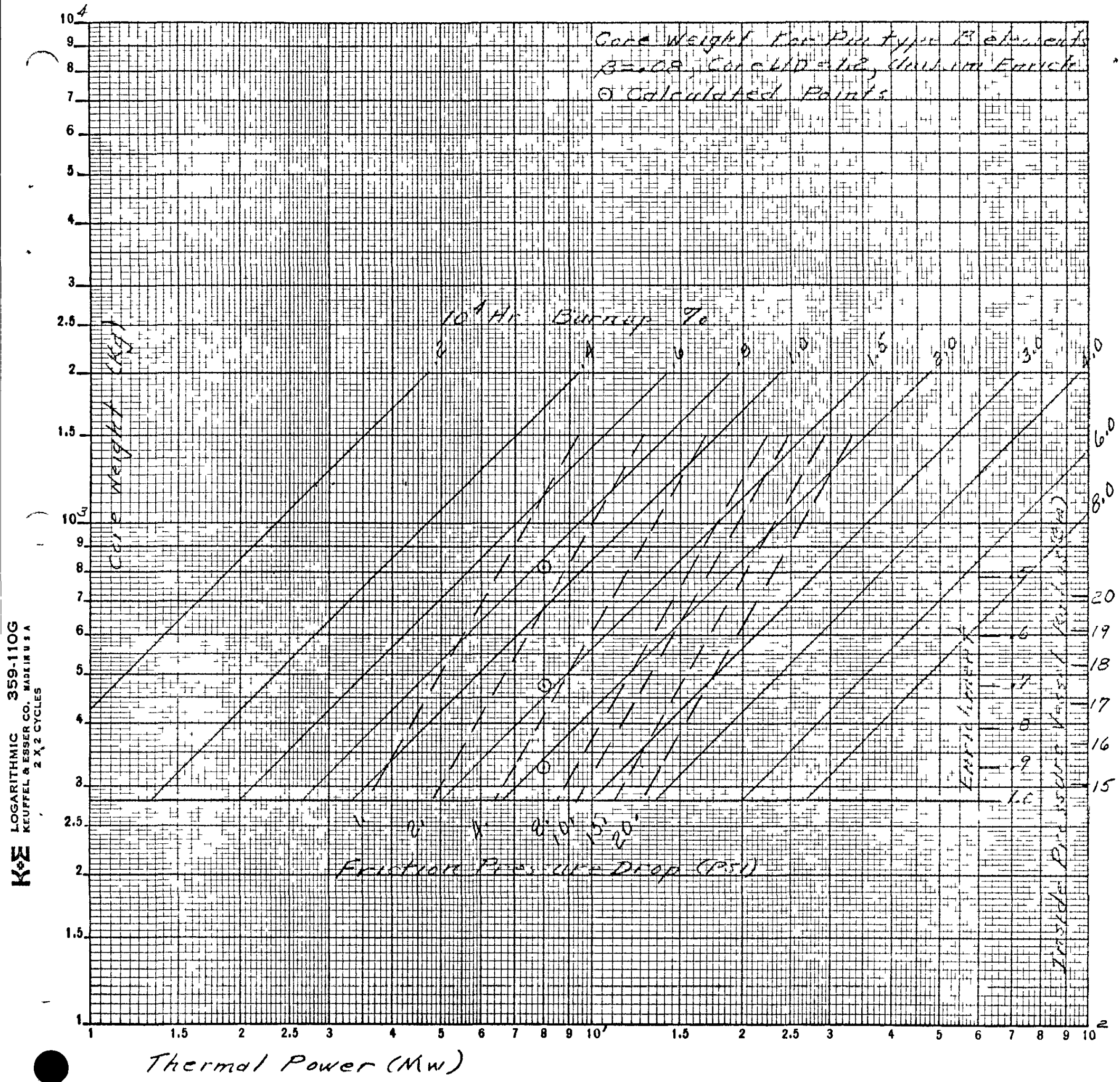




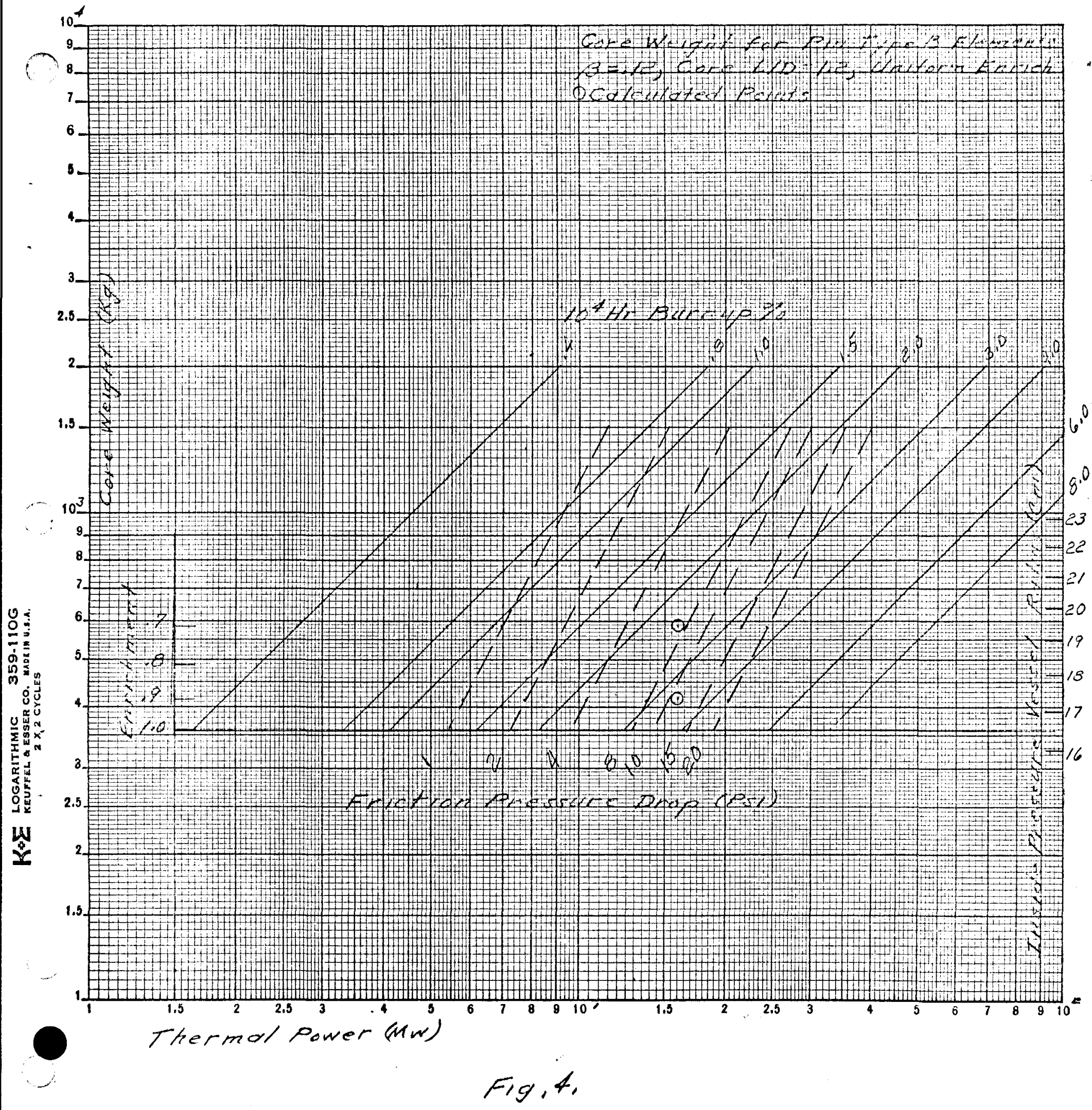




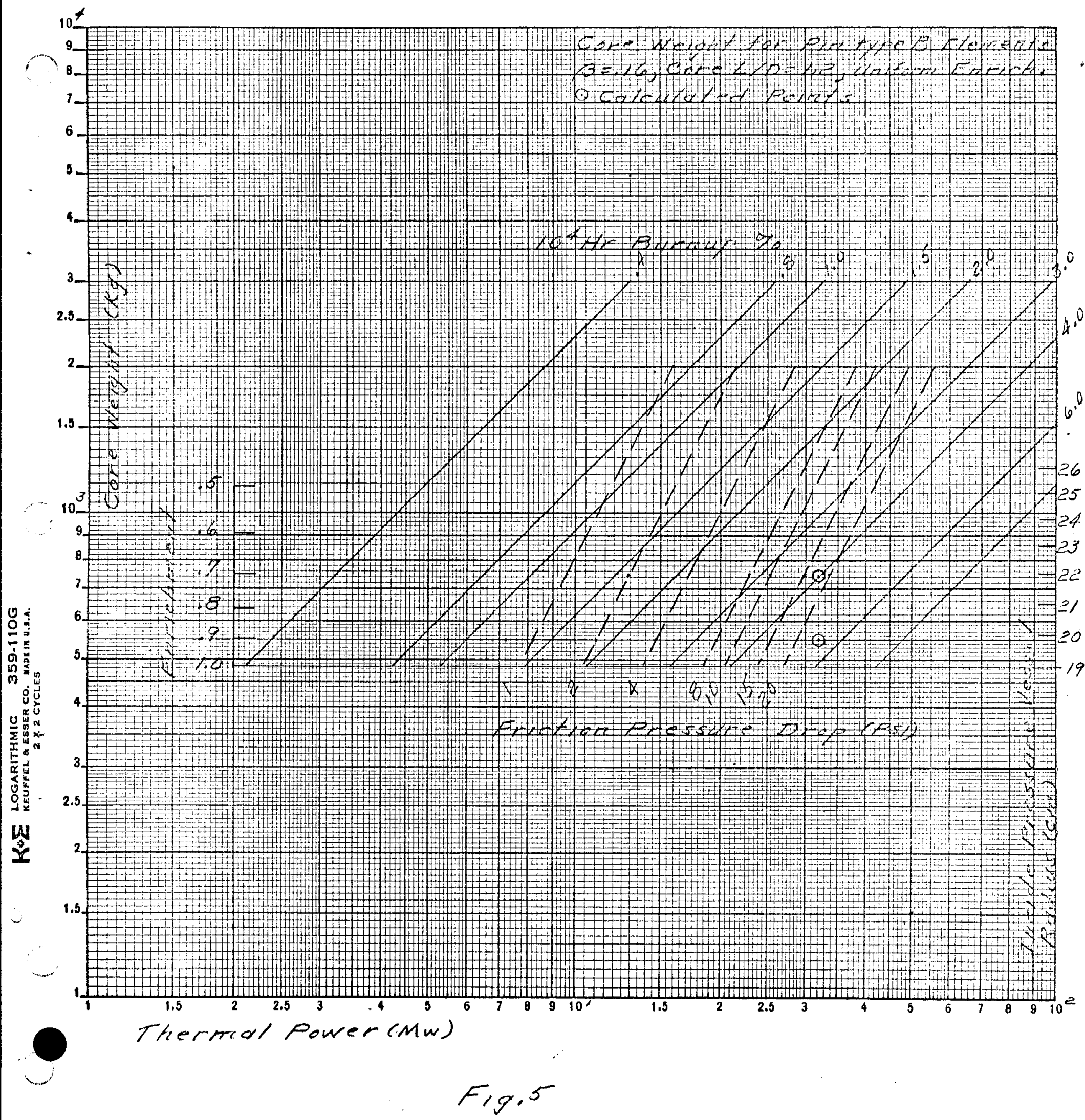




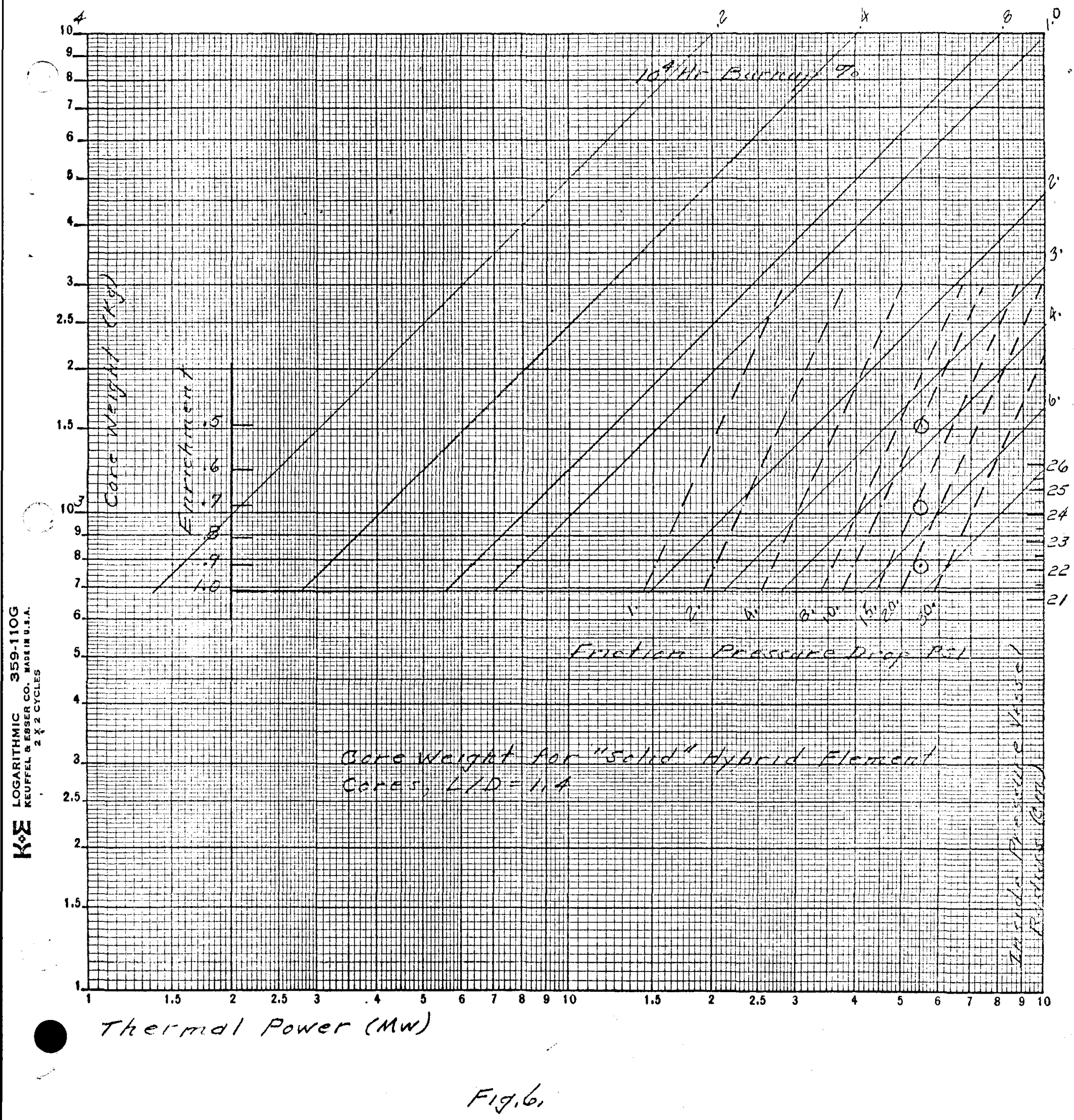




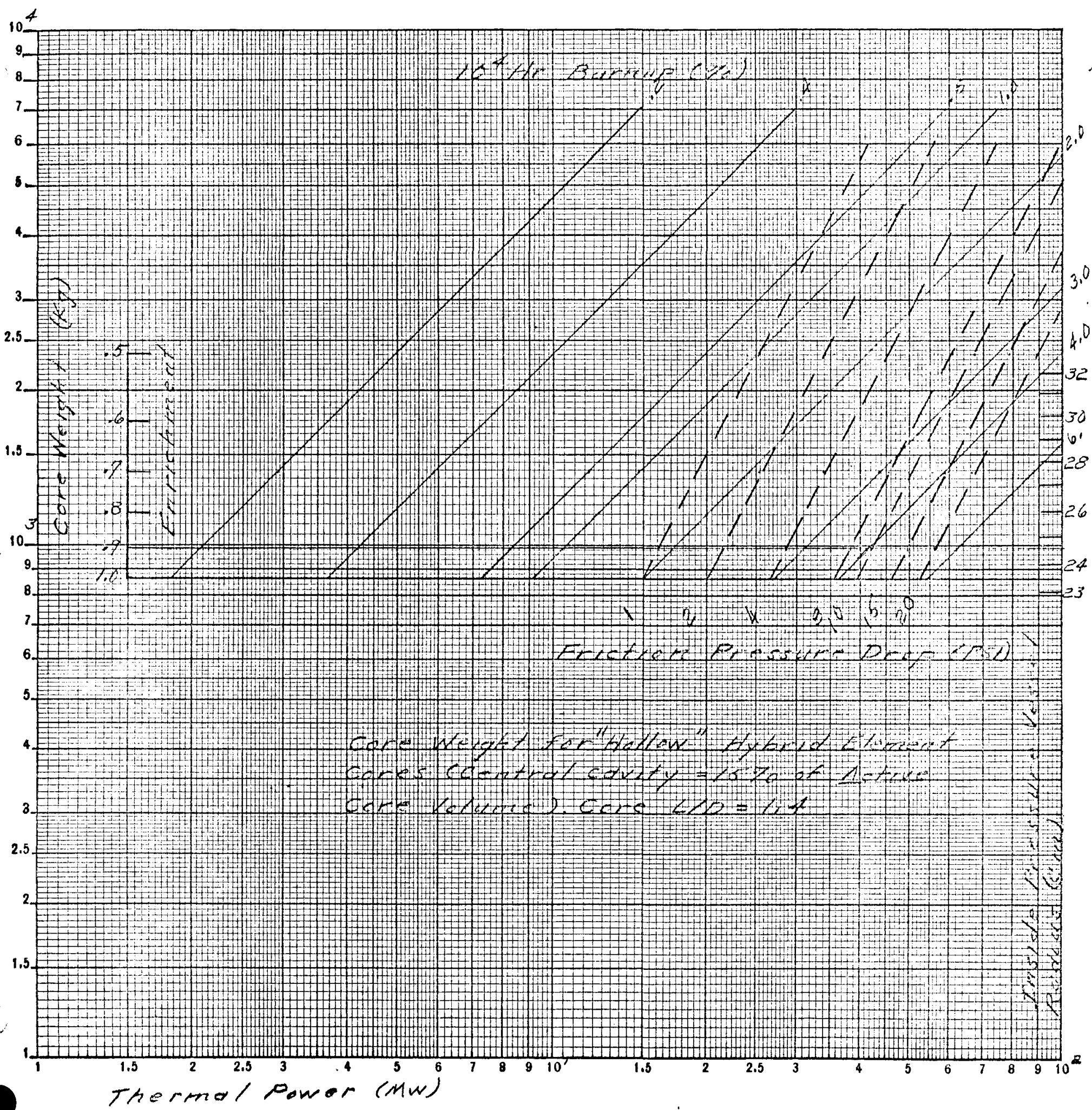

$$
\text { F,g.? }
$$


10 SPN NO. 225 - JuTy 7, 1967

Page 15

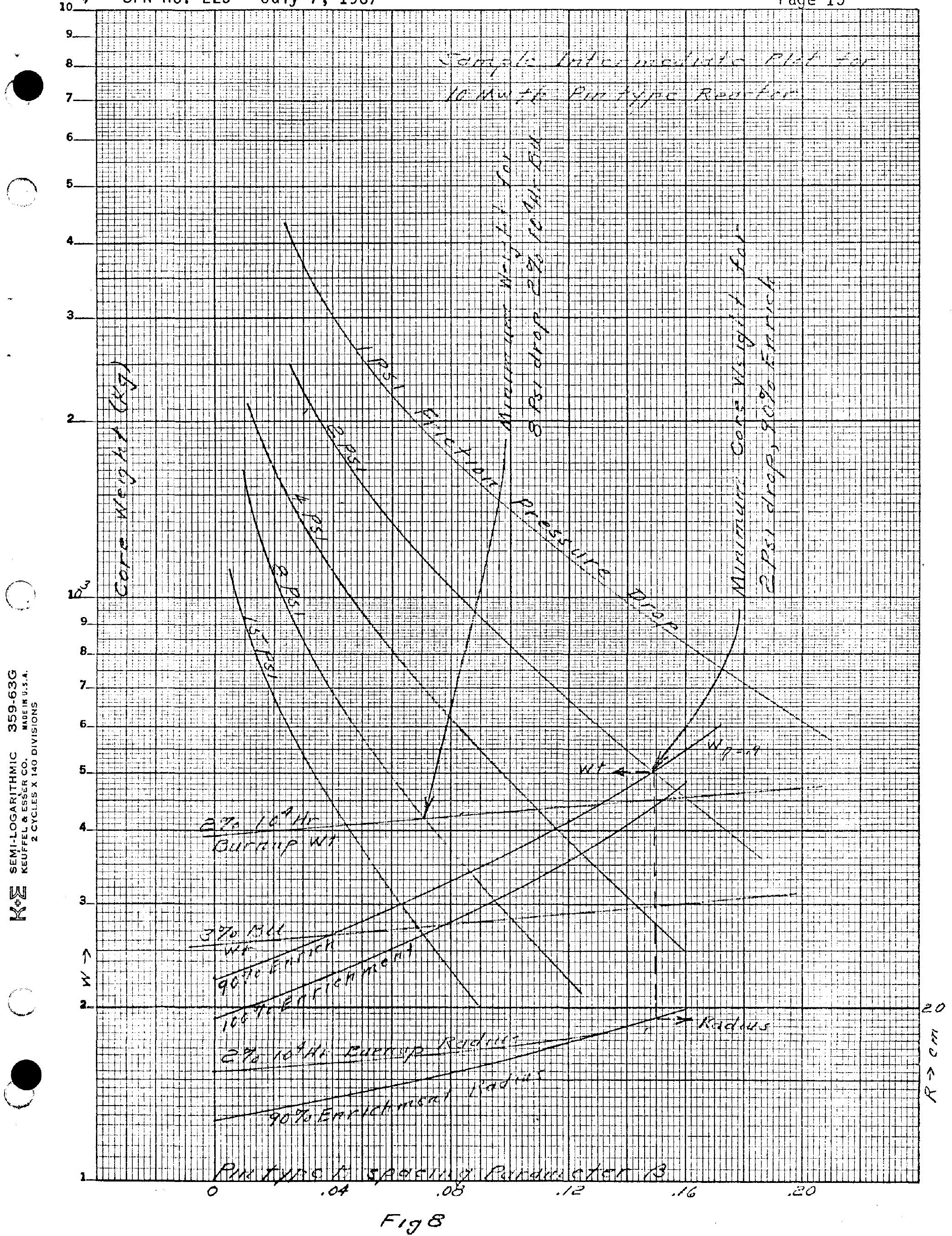




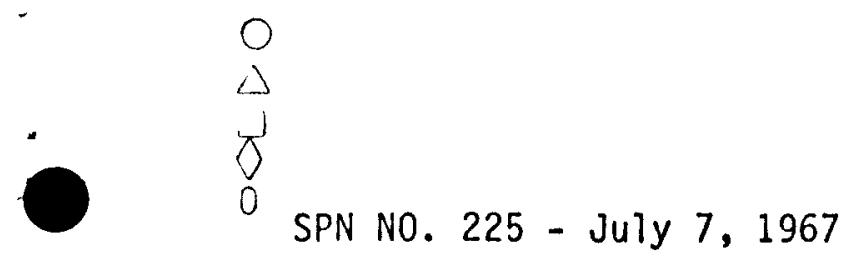

Page 16

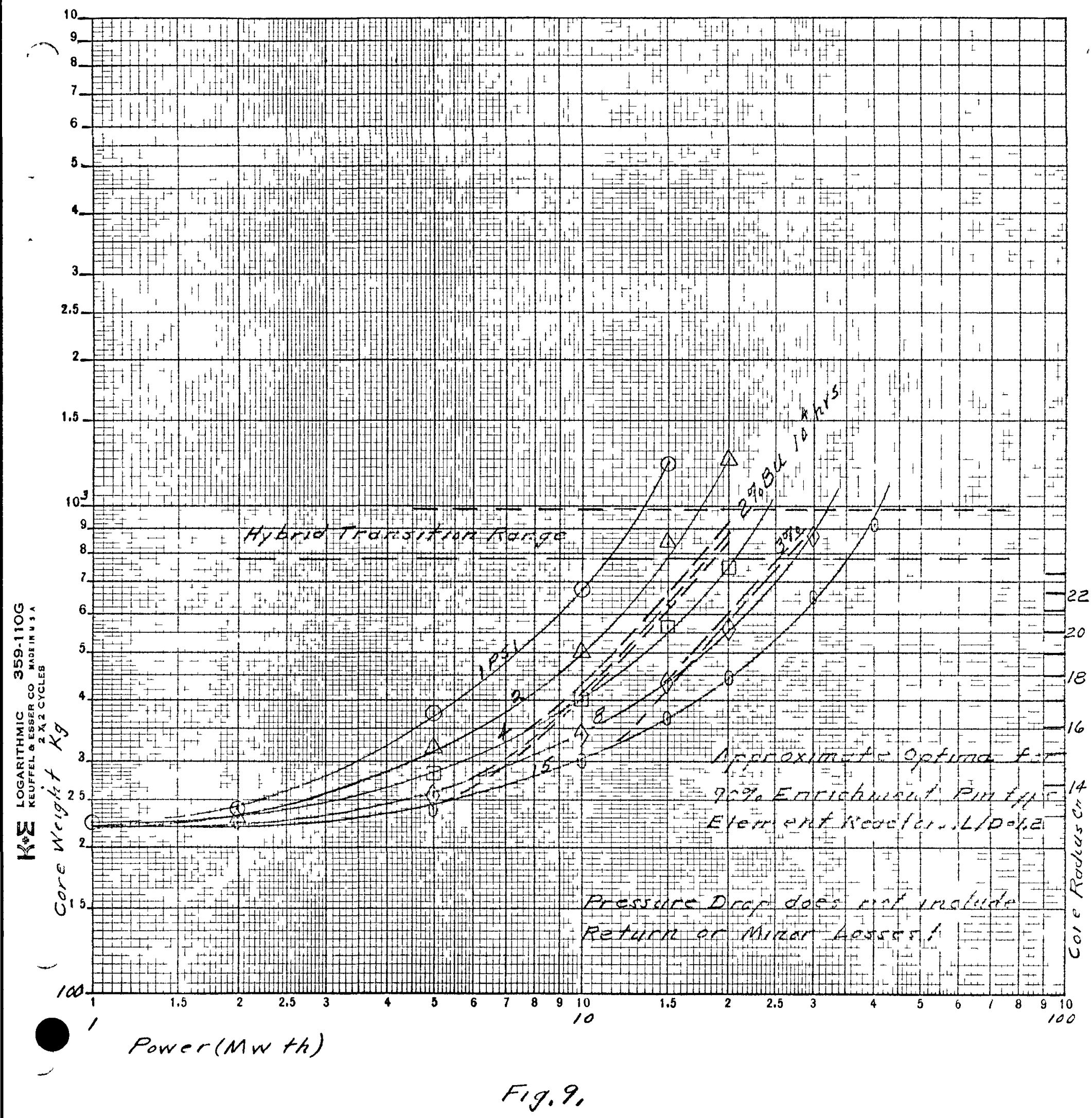




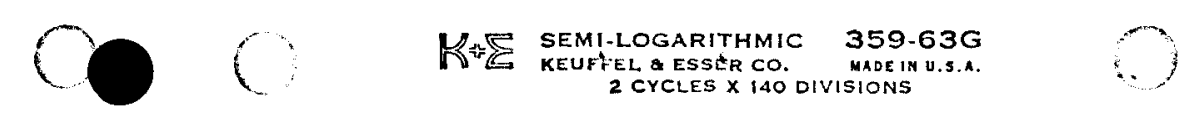

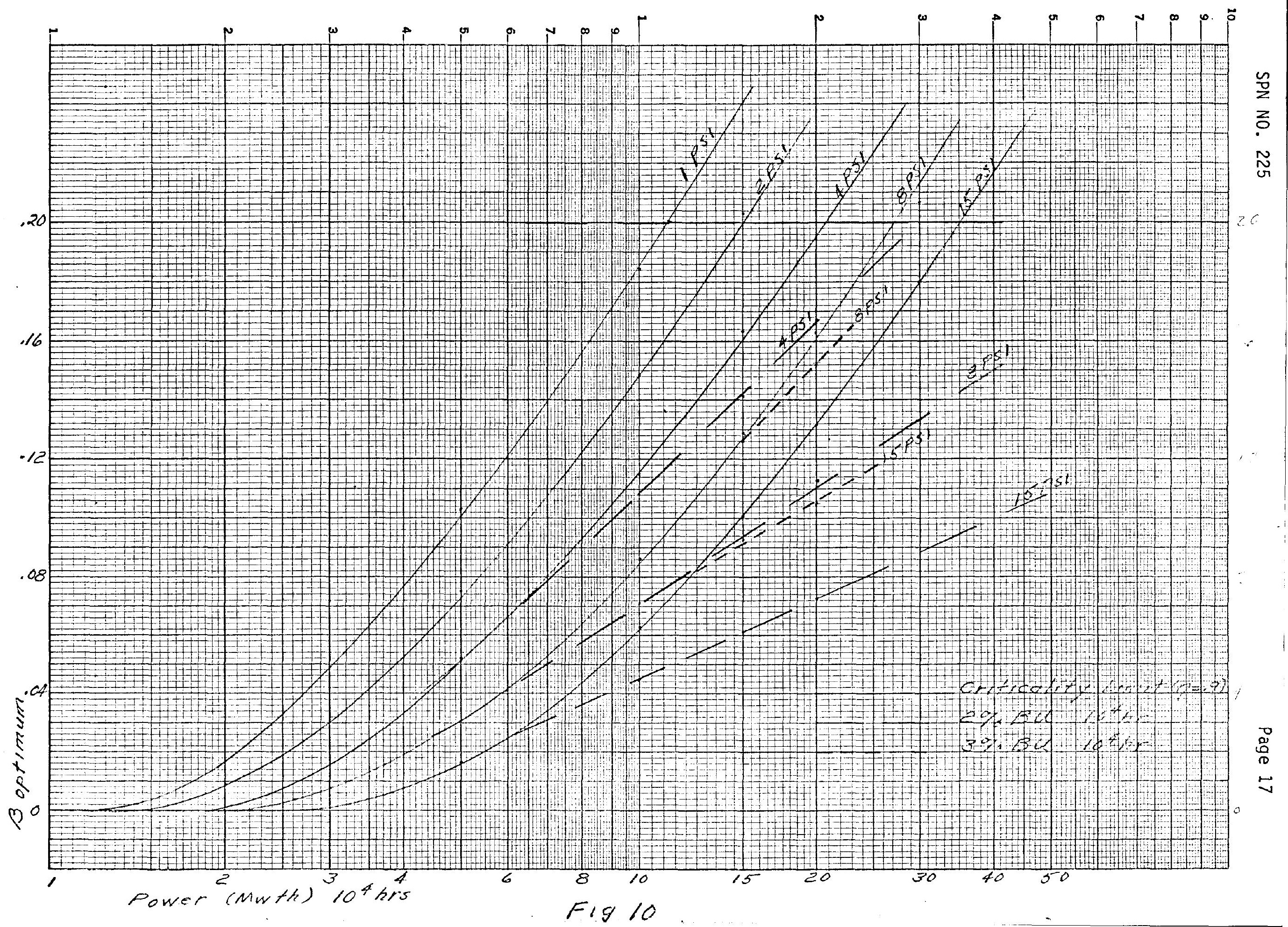


OISTRIBUTION:

U. Hadley

3. Hadiey/file (5)

ir. Heusinkveld

O. Kolar

G. Cummings

T. Stubbs

J. Howara

W. Loewe

N. Brown

P. Mohr

3. Pitts

3. Myers

3. Mivers/File (5)

W. N. Ross

C. Walter

W. Wells
R. Herner

C. Journeay

J. Freeman (2)

L. Roberts

B. Rubin

R. Batzel

R. Heckman

J. Kane

H. Finn

A. Rothman

R. Vandervoort

' H. Teifeld

Patent Engineering

Edward S. Wilson, AEC-Washington

LEGAL NOTICE

This report was prepared as ant account of Government sponsored work Nerther the United States nor the Commission nor any person acting on behalf of the Comrission

A Makes any warranty or representation expressed or Impled with respect to the accuracy completeness or usefulness of the information con lained in this report or that the use of any information apparatus method or process disclosed in this report may not infunge privately owned nights or

B Assumes any labolities with respect to the use of or for damages resulting thom the use of any infornation apparatus method of process dis closed in this report

As used in the above person acting on behalf of the Commission" includes any employee or contractor of the Commissson of employee of such contractor to the extent that such enployee or contractor of the Commission or employee of such contractor prepares disseminates or provides access to any intosmation pursuant to his employment or contract with the Commission or his erployment with such contractor 